\title{
Guidance and Counseling Implementation Model in Strengthening of Student Character of Islamic Middle School
}

\author{
Riyono $^{1}$, M. Ali Sibram Malisi ${ }^{2 *}$ \\ ${ }^{1}$ Student of Post graduated Study of IAIN Palangka Raya \\ ${ }^{2}$ Doctor of Islamic Education, State Institute for Islamic Studies (IAIN) Palangka Raya
}

*Corresponding Author: M. Ali Sibram Malisi, Doctor of Islamic Education, State Institute for Islamic Studies (IAIN) Palangka Raya, Indonesia

\begin{abstract}
The implementation of guidance and counseling program has been running with the number of class hours to perform classic services on a regular basis one hour of lessons a week. Then there are some services that are carried out incidentally. But the implementation of the services that should be provided is not all carried out such as group counseling services, as well as supporting activities such as instrument applications and data sets do not exist. Due to the lack of ability of counsellors in creating service programs, as well as the lack of infrastructure owned by madrasah, the implementation of guidance and counseling services did not run optimally, as a result of violations of madrasah discipline, especially in terms of discipline continues to repeat itself. The guidance given is incidental so that it gives less deterrent effect.
\end{abstract}

Keywords: Implementation, Guidance and Counseling, Character

Abbreviations: MTs: Madrasah Tsanawiyah, PPKP: PondokPesantrenKarya Pembangunan, GC: Teachers Guidance and Counseling Teachers, Permendikbud: Peraturan Menteri Pendidikan dan Kebudayaan, MOEC: Ministry of Education and Culture

\section{INTRODUCTION}

The education in Madrasah (Islamic school) is the process of education during the transition of children from the age of children to adolescence. In this age, children are vulnerable to various influences, both positive and negative influences from the surrounding environment, namely in the madrasah environment and in the neighborhood where they live. At this age it also includes adolescence. Adolescence is a very important time for future development. In adolescence, students try to find their identity, achieve emotional independence, maturity of social relationships, and prepare for a career. Character building for learners is expected to be able to provide knowledge to students in order to distinguish between positive and negative influences so that they do not fall into negative things. Giving the importance of character building, education in madrasah aims to produce positive changes in students who are in development towards self-maturity. To achieve this goal, madrasah have developed three subsystems, namely administrative subsystems, teaching subsystems, and assistance or coaching students subsystem. The three work together according to their respective functions to achieve national education goals.

Education programs in schools to strengthen the character of students through harmonization of knowing, feeling, and acting, with the support of public involvement and cooperation between schools, families, and communities that are part of the National Movement for Mental Revolution (GNRM), the benefits that can be obtained is human resource development is the foundation of nation building; 21st century skills needed by students: Character Quality, Basic Literacy, and Competence $4 \mathrm{C}$, in order to realize the competitive advantages of the Golden Generation 2045, the tendency to degrade morality, ethics, and ethics. (Article 1, The Ministry of Education and Culture (MOEC) No. 20 of 2018).

The education and teaching process should synergize with guidance and counseling services in fostering the character of students in Madrasah. The success of a mentoring and counseling process can be influenced by two things, including; firstly communication between teachers and students that goes well and correctly during learning and outside of learning, secondly the implementation of good 
guidance and counseling in madrasah. Strengthening student character building can be realized through guidance and counseling management. This is because formal education in Islamic middle school or Madrasah Tsanawiyah (MTs) has greater demands for the future of the students. In addition, it is also preparing children in facing the best possible life, both as a person, family member and as a member of the community.

Some development of the guidance and counseling services global trends seem to have changed from the goal of improving preventive approaches in the provision of guidance and counseling developed (Gysbers\&amp; Henderson, 1994; Yuen, 2002; Lai-Yeung, 2014). Hence guidance and counseling is an indispensable therapy for school children (Durojaiye, 1999)

Mistakes often occur in terms of understanding, that the role of GC teachers only deal with students who have some problems or violate the rules in madrasah, such as bullying their own friends in the classroom, fighting and so on. So, the violation will continue to repeat itself because there is almost no preventive effort. Whereas if observed, the role and function of guidance and counseling are more than that, with the guidance and counseling services in madrasah, it is expected to be able to shape the character of students so as not to repeat what has been done before. (Ebizie Elizabeth Nkechi, 2016)

Various misunderstandings and cases of malpractice that occurred in guidance and counseling services so far, various misperceptions about them, as happened in MTs PPKP Sampit, the symptoms of existing them are more likely to scare students against their teachers, so that students who experience problems in their education are less courageous to be honest and prefer to be silent if they face problems. It is more likely that it is closely related to the level of understanding and mastery of counsellors on the basis of guidance and counseling, in other words, the organizing of guidance and counseling is carried out originally, not built on a foundation that has good management. (observation, 2021)

MTs PondokPesantrenKarya Pembangunan (PPKP)Sampit is one of the madrasah with the largest number of students in East Kotawaringin Regency even able to exceed the number of students in one of the state Islamic Middle School, namely MTsN 2 Kotim. But the ratio between students and the number of teachers is not comparable, especially guidance and counseling (GC) teachers are still not in accordance with the standards set out in the ministry of Education and culture number 111 year 2014 on guidance and counseling, namely one GC teacher at most 150 students. Meanwhile, in MTs PPKP Sampit twoGC teachers serve 544 students. This means that one GC teacher has 272 students. It is far from the maximum number they should be. This is related to the limited funds owned by MTs PPKP Sampit to increase the number of GC teachers. However, for me it will be able to be resolved if the management of guidance and counseling has a directed and systematic management.The services are still afflicted by such problems as lack of adequate trained personnel, poor attitude of parents, principals, teachers, students, government e.t.c. (Egbo, 2012)

Amid the limitations of both the ability to understand counselors and funding and the ratio between the number of GC teachers and the number of students, there are a number of achievements achieved by MTs PPKP Sampit students, among whom were able to become general champions in the (International Committee of Red Cross (PMR) competition in East Kotawaringin district for three consecutive years, namely from 2010, 2011 and 2013. General champion of district-level drumband in 2017 and 2018. In fact, some of the students who participated in the competition used to be students who had been called by GC teachers to be given guidance for violating madrasah discipline, especially in terms of discipline. It cannot be denied that GC teachers successfully conduct coaching on the character of students in MTs PPKP Sampit (observation, 2020). Not only that, in 2019, one of the students was able to become the first champion in the sport of pencaksilat at the East Kotawaringin district level. Uniquely, these students are who often violate the madrasah's code of conduct so that they are often called for coaching by GC teachers.

This research aims to examine the achievements of a goal implemented in a quality guidance and counseling program in relation to the development of student character. Thus, guidance and counseling teachers need a good ordinance or implementation in order to facilitate in achieving the 
goals expected in building the character of students. So that, one of the functions of guidance and counseling at schools is Preventive function. (NilaKusumawati, 2008)

\section{LITERATURE REVIEW}

From research which has been conducted by researcher about implementation guidance and counseling, the study both examined that in terms of the character of students and the same school level. However, the research also has differences, namely the focus of the research only discusses the role of guidance and counseling teachers and specifically identifies the character of students.

Research conducted by Soheno (2019), showed the planning of student development at SMK Muhammadiyah 2 JatinomKlaten Regency, conducted every beginning of the new school year by preparing an annual program, collecting student data, providing orientation services to new students about the state of the school, new school environment, introduction of school facilities, organizing process that includes the preparation of tasks, the formation of programs and also the determination of the implementation of guidance and counseling activities determined by the supervisory teacher and counseling determined by the supervisory teacher as the coordinator as well as the main implementation of the guidance process and counseling in SMK muhammadiyah 2 Jatinom, Implementation of counseling guidance in coaching students using a pattern of $17+$ that is with additional Islamic character education, Evaluation of guidance and counseling in student coaching which is the activity of guidance and counseling services evaluated including: Individual and group counseling, consultation with students, parents, and teachers both individual and group, measurement of interest, ability, behavior, student learning progress, and coordination of guidance and counseling services for students in schools.

Research by Yusri (2016), the results of the research include: forms of guidance and counseling at high school in Sabang City include orientation services, information services, placement services, content mastery services, individual counseling services, group guidance services, group counseling services, consultative services, mediation services, instrument applications, data sets, case conferences, home visits, library displays, and case hand-over, obstacles in the implementation of guidance and counseling services are the un-availability of face-to-face hours with students and facilities that are still lacking.

Research conducted by HelmiSupriyanti (2017), the findings of this study are: The program planning stage in guidance and counseling services in State Senior High School (SMAN 1) Sampit has been done properly and correctly in accordance with applicable rules, although for individual counseling service programs were not being programmed because it is a responsive service, At the step of implementation of Guidance and Counseling services in SMAN 1 Sampitis incidental, i.e. at any time without scheduled time allocation. While it should be responsive according to the needs of students. The control stage of guidance and counseling services at SMAN 1 Sampit conducted and documented is LAPELPROG (Program Implementation Report) guidance and counseling, while program evaluation and follow-up programs were not carried out by the guidance and counseling coordinator.

The research conducted by Suleman (2019), with the title of Research on Character Identification of Millennial students and their Effect on Learning Motivation and The Role of Guidance and Counseling Teachers at State Middle School (SMP Negeri 1)PerbaunganSerdangBedagai Regency. The results of this study include: The character of millennial learners who are observed daily is finally identified from their attitudes and attitudes, it turns out that the effect of the development of information technology that continues to permeate all aspects of students' lives in and outside school, guidance and counseling teachers in schools have a very important and strategic role to address the development of learners. Whether it concerns the personal, learning, social, and future careers of students.

At the beginning of development, the sense of guidance is only limited to guidance in office and career improvement. Then it develops towards a broad understanding of guidance covering aspects of education, social, family and etc. Some experts give the meaning of guidance. Hibana (2013) mentioned that "guidance is the process of assistance given to a person who able to understand, adjust and develop himself in order to achieve a successful and happy life." Hibana concept may be 
understood that guidance is a human process of understanding that the nature of life to achieve success and happiness that could be realized from understanding yourself, which then in terms of social is adjusting and ultimately achieving self-development.

Hallen (2012: 9) stated about the guidance is as follows: Guidance is the process of providing continuously assistant from a supervisor who has been prepared to the individual who needs it in order to develop all the potentials, optimally using a variety of media and guidance techniques in a normative atmosphere of upbringing in way of achieve self-reliance. Thus, the individual can benefit both himself and his environment. Furthermore, the word counseling comes from the word counsel that taken from the Latin counselium, meaning to be together or to talk together. The sense of talking together in this case is a counsellor's conversation with one or several clients. (Latipun: 2010:3)

At the beginning of its development in Indonesia, the term used was 'counseling'. But since the 1980s the term counseling has been changed to counseling. It is intended to distinguish the terms of agricultural counseling, legal counseling and so on. While counseling is devoted to guidance in the field of education.

Tohirin (2007: 21) means that counseling is an integral part of guidance. Counseling is also one of the techniques in guidance. In other words counseling is the core of guidance. And some argue that counseling is his "heart" guidance. So that the practice of guidance can be considered as not there if there is no counseling. Meanwhile, Ketut (2008: 34) revealed that counseling is a one-on-one or faceto-face relief effort between counsellors and clients that contains a barreled, unique, human (human) effort, conducted in an atmosphere of expertise and based on prevailing norms, in order for the client to obtain the concept of self and self-confidence in improving his behavior at this time and perhaps in the future.

From the above opinions about counseling it can be said that counseling is the process of providing assistance from a counsellor to the counsellor in the form of advice or advice aimed at changing the behavior of the counsellor using certain counseling techniques.

Implementation is a process to achieve goals that serve to realize planning and organizing with the provision of motivation, direction and influence to all members of the group in order to work consciously and willingly. In this implementation function, guidance and counseling carried out by the teacher guidance and counseling, coordinated by a coordinator of guidance and counseling.

In the implementation of guidance and counseling, the method is a way of counsellors in helping students when undergoing the counseling process. The existence of methods always have an important role in conveying educational messages and counseling activities, so that it can be ascertained that one of the successes in achieving the target and objectives of counseling in school is to establish the method used. That is, the use of methods by considering the right subject in terms of the problems faced by students and the targets to be achieved must be thoroughly and thoroughly considered.

According to Tohirin (2007), in his book entitled Guidance and Counseling in Schools and Madrasahs (Integration-Based), in general there are two methods in guidance and counseling services, namely group guidance methods, and individual guidance methods (Individual Guidance).

Group Guidance Method. This is done to help students in solving problems through group activities. Group guidance is intended to help solve problems together or help an individual who is facing problems by placing them in a group life.

Individual Guidence Method. In individual guidance, counsellors or tutors are required to be sympathetic and empatned. Sympathy is shown by the counselor through the attitude of feeling what the student is feeling, while empathy is the effort of the counselor to put himself in the situation of the student with all the problems he/she faces. The success of sympathetic and empathetic counsellors will give full trust to counsellors and will also help the success of the mentoring and counselling process.

The implementation of guidance and counseling leads to the implementation of guidance and counseling programs that have been planned, this is strongly related to the services of guidance and counseling. In order for the implementation of guidance and counseling services to run properly, the 
counsellor must: Be able to create a conducive working atmosphere; Synchronize between the purpose of guidance and counseling with the purpose of guidance and counseling officers. Creating harmonious relationships. Optimizing the potential of guidance and counseling officers. Placing guidance and counseling officers according to their abilities and characteristics.

\section{Methodology}

\subsection{Type, Place and Time of Research}

Type of research. This research was a field research, which is a study that examined objects in the field to dig up data and a clear and concrete picture of matters related to the problems that are examined (Sugiyono, 2012). Researchers jumped directly into the field to conduct research on the implementation of guidance and counseling in MTs PPKP Sampit in fostering the character of students, namely the character of discipline and social care. Devoted to these two characters because these two characters are the most dominant violations occurred in MTs PPKP Sampit. The method used in this research is qualitative method which is research procedure that produces descriptive information in the form of written or oral sentence description of people and observable behavior. Qualitative method in this research was chosen to get detailed and detailed information about implementation which includes planning and implementation of guidance and counseling in MTs PPKP Sampit, so that the quality or depth of data can be obtained.

Place and Time of Research. The location of this research is in MTs PPKP Sampit. This madrasah is located at JalanPelita number 127, MentawaBaruHilir Village, MentawaBaruKetapang District, East Kotawaringin Regency, Central Kalimantan Province, under the name PondokPesantrenKarya Pembangunan (PPKP) foundation established since 1986, with the status of madrasah trakreditasi quite dated November 23, 2016, which has Notarial Deed No. 24 dated May 13, 1977 with a land area of 100 meters X 200 meters with land status Grants from the Regional Government level II KotawaringinTimur, with institutional decree WP / 5.d / PP.0.05/146/1994 Dated 01 October 1994, NSS from the Education Office numbered 212140401001 and NSM from the Ministry of Religious Affairs with the number 121.2.62.02.0003.

The choice of this madrasah as a research location because the management of counseling guidance in the development of students in MTs PPKP SampitKotawaringinTimur regency has not run in accordance with existing theoretical concepts, because the lack of management of counseling guidance in the development of student character in MTs PPKP SampitKotawaringinTimur Regency, as well as the ratio between the number of students and GC teachers is still not in accordance with the standards set in the rule of the ministry of education and culture (Permendikbud) No. 111 year 2014 on Guidance and Counseling. According to Rully and Poppy "Qualitative findings are directed to produce improvements in the quality of work and can also basically be beneficial for academic purposes."

In addition, researchers have also been very familiar with and understand the cultural conditions that exist in the place of research. This is in accordance with the opinion of Rully and Poppy (2016) which states "It is good that research using qualitative methods before conducting research must really understand the cultural conditions or whatever is in place of research."

\subsection{Data and Data Source}

The primary data was obtained directly from the research subjects, namely two guidance and counseling teachers at MTs PPKP Sampit, in the form of verbal or verbal speech and behavior from the research subjects, and for more details, data was also obtained directly from informants related to planning, organizing, implementation and supervision of guidance management and counseling and problematika in fostering student character in MTs PPKP Sampit.

Secondary data consists of documents, photographs, and objects that can be used as a complement to the primary data. Secondary data characteristics are writings, recordings, pictures or photos, related to planning, organizing, implementation and supervision of guidance and counseling and problems in fostering the character of students in MTs PPKP Sampit.

The data source in the study was the subject from which the data can be obtained. (Arikunto, 2002: 129) In this study using two data sources, namely: Primary data source, which is data directly 
collected by researchers from the first source. In this study, the primary data sources were two guidance and counseling teachers at MTs PPKP Sampit as research subjects, and data from informants namely deputy head of madrasah in curriculum field, Deputy head of madrasah in student affairs, homeroom teacher and student who had been actively involved in fostering guidance and counseling services.

Secondary data sources, namely data collected by researchers as supporting from primary data sources. Secondary data sources in this research were madrasah mission vision, guidance and counseling programs (Prota, Promes, Probul, Proming, Proha), guidance and counseling instruments, data on students, organizational structure of guidance and counseling, satlan and satkung guidance and counseling, and evaluation report of guidance and counseling activities in MTs PPKP Sampit. Data collection techniques are a way used for data collection, data collection activities are important work in researching. The techniques used for data collection in this research are observation, interview, and documentation.

\subsection{Data analysis Technique}

Data analysis in qualitative research, conducted at the time of data collection, and after completion of data collection in a certain period. At the time of the interview, researchers had already analyzed the answers interviewed. If the answers interviewed after being analyzed feel unsatisfactory, then the researchers will continue the question again, to some stage so that data is obtained that is considered credible.

The steps taken in analyzing the data technically refer to the steps put forward by Miles and Huberman (2002). There are four components that are done with this model, namely data collection, data reduction, data display and inference.

\subsection{Data validity technique}

Data validity technique is a technique used to prove whether the research is really scientific, as well as to increase the degree of trust of data obtained by researchers. In this study, researchers in finding the validity or validity of data using data trianggulation techniques. Trianggulation is a technique of checking the validity of data that utilizes something other than data for the purpose of checking or comparing the data. (Moleong, 2004)

Data triangulation technique used in this research is source triangulation technique, namely comparing and checking the degree of trust of information obtained. According to Moleong this can be achieved in a way: Comparing the observation data with the interview data, comparing with what the informant said with the other informant. comparing the state of one's perspective with the different opinions of others. Compare the results of the interview with the contents of a related documentation. (Moleong, 2004)

The triangulation of sources carried out in this study in the following way: Comparing the observation data with the data of interviews with teachers, students and deputy heads of madrasah MTs PPKP Sampit. Compare what teachers say to each other. Comparing the perspective situation of a teacher with the opinions of other teachers, namely the homeroom teacher at MTs PPKP Sampit who is actively involved in the character building of students. Comparing the results of the interview with the content of a documentation that has to do with the management of guidance and counseling in the character building of students in MTs PPKP Sampit, namely the character of discipline and character of social care.

With the source triangulation technique, researchers compared the results of interviews obtained from each source or research informant as a comparison to check the correctness of the information obtained.

\section{Result and Discussion}

\subsection{Planning for the implementation of Guidance and Counseling in the Development of Student Character in PPKP SampitMTs.}

Planning is carried out as a first step to improve the quality of guidance and counseling management in order to have a good quality so that it will support the achievement of the objectives of guidance 
and counseling services. The activities in management planning guidance and counseling are as follows:

Analysis of student needs. The first thing that counselors do in guidance and counseling planning activities is an analysis of students' needs and the problems they face. Analysis of student needs is the activity of counselors collect all data about students who fostered both personal data, background, social environment and other data. This activity as stated by the coordinator of guidance and counseling at MTs PPKP Sampit "First the data entered through the administration there are already details of all parents' names, parental work, parental education, distance from home with school, these are all data that help us to make counseling guidance planning. The goal is that we first look at what problems we are facing, with us understanding the problem we can determine what goals we want to achieve in this guidance and counseling." (interview, 2021). The same thing was also conveyed by the counselor at MTs PPKP Sampit: "First to make observations, observations whether, without observation there may not be reports of this child is problematic or not, with the observation we can get to know the child, we see the background of the child, the background of the parents, his association, we see his background from home, because the data in school is not necessarily appropriate. After that we just build a GC service program. We dig information about what problems faced by the child, secondly we can read this child is problematic or not, this information we obtained by doing information in the field, directly to the child, if it can be directly to both parents. All this time I did directly with his parents. That's why if there are activities his parents already know that there is this ..." (interview, 2021)

Analysis of the situation and condition of the school (environment). In this activity, counselors must know the policies in their schools, know the reality of the school, know the situation and condition of the school that can affect the development of its students. MTs PPKP Sampit takes the policy by allocating 1 hour of lessons (40 minutes) of guidance and face-to-face counseling services in the classroom each week. But the time given is still insufficient, If seen from the amount of time provided for GC services I think it is still not maximal. Because per week students are only given face-to-face time for $1 \mathrm{x} 40$ minutes only.

Because the time given is quite limited, this makes the role of guidance and counseling in coaching the character of students has not been maximal, this was revealed by Mr. Eh as the vice-principalof student affairs: "The role of guidance and counseling in coaching the character of students is not maximum, because there is no coaching or scheduled service, it is only incidental, so there are no prevention efforts against violations, for example, violations of student dissipance, such as delays in attending school, the way students dress that do not comply with the rules, this is constantly repeated. At the time of observation, it is known that the guidance and counseling teacher is also involved in the picket, so that in case of violation, then the guidance and counseling teacher can immediately find out and coordinate with other teachers, especially the guidance and counseling teacher.

Determination of guidance and counseling objectives. The purpose of guidance and counseling is a reflection of the vision and mission of madrasah, so that in setting goals must be adjusted to the vision and mission of madrasah. Based on the results of interviews with the vice-principalof student affairs, it can be known that the planning of guidance and counseling programs is in accordance with the vision, mission, and objectives of madrasahs. The same thing was also expressed by the deputy head of madrasah in curriculum field in the interview, he said: The GC program has been well planned in accordance with the vision, mission and objectives of MTs PPKP Sampit. This can be seen from the programs created by GC teachers, both annual programs and semester programs. Of course, in determining the objectives of the guidance and counseling program, the things that must be our handle and direction are the vision, mission and objectives of the madrasah, whether the program that we have arranged is in accordance with the vision, mission and objectives of madrasah."

Based on the results of documentation of the vision, mission, objectives, and programs compiled by counselors, both annual, semester, monthly and daily programs, has been in accordance with the vision, mission and objectives of madrasah. For vision, mission, goals and programs yearly, semester, monthly and daily can be seen in attachments about vision, mission, goals and programs guidance and counseling. 
Determination of the type of activities that will be carried out. Based on the documentation of program planning and guidance and counseling services MTs PPKP, is as follows: Orientation, which is a service that helpsstudents understanding the new environment, especially the school / madrasah environment and the objects studied, to adjust and facilitate the role of them in the new environment. Information, which is a service that helps students receive and understand various information themselves, social, learning, career / position, and further education. Placement and distribution, which is a service that helps students obtain the right placement and distribution in the classroom, study groups, courses, training programs, internships, and extra-curricular activities. Content Mastery, which is a service that helps them mastery certain content, especially competencies and or habits useful in school life, family, and community. Individual Counseling, which is a service that helps students in alleviate their personal problems. Group Guidance, which is a service that assists students in personal development, social relations skills, learning activities, career/position, and decision making, as well as conducting certain activities through group dynamics. group counseling, which is a service that helps students in the discussion and alleviation of personal problems through group dynamics. Consultation, which is a service that helps them and or others in gaining insight, understanding, and ways that need to be implemented in dealing with the conditions and or problems of students. Mediation, which is a service that helps students solve problems and improve the relationship among them.

Determination of time and type of activity. The time and type of guidance and counseling services activities in MTs PPKP Sampit have been made a face-to-face schedule, so that services can be provided in the classroom. In addition, guidance and counseling services are also provided outside the stipulated time, but services outside the stipulated time are incidental and less maximal. This was expressed by the vice-principle of student affairs as follows: "the implementation of guidance and counseling activities has not been in accordance with the planned program, there is no regular scheduled coaching of students, especially those who have indications of violations, there is only coaching, handling in the form of sanctions when there is a serious violation. because there is no coaching or scheduled service, it is only incidental, so there are no prevention efforts against violations, especially severe violations of students" (Interview, 2020).

Determination of facilities and cost of activities. Based on the observations, physical facilities such as special guidance and counseling rooms, tables, chairs, and cupboards where data storage is available even though the condition is still inadequate because the existing room is still integrated with other buildings, such as TU rooms, and kitchens. This resulted in a lack of maximum guidance and counseling services provided to the counsel. Regarding this physical facility was also expressed by the coordinator of guidance and counseling in the interview results as follows: Speaking of facilities that can be seen by, "I am not flattering the father as the principal, new school year my father had his own room, had an organizational structure, had a place even though the place was still passing by but that I am grateful it is already a place we are given by the institution. I hope in the future I have a more present place. Not that the guidance and counseling room should not be visited by anyone, it's fine. But we see in the school that the public sir, where I used to practice in High School 3, it was very, very quiet, behind the school room, behind the teacher's room, that one of the kids was close to us, the kid wanted to talk to us was he was sure we could hold him safe, he felt safe". In line with the guidance and counseling coordinators, GC teachers also said that the consultation room for guidance and counseling is inadequate and exposed out, its room should be closed. For technical facilities, such as questionnaires, tests, checklists, and inventory, according to the observation results are still incomplete. Both counselors do not have complete instruments of guidance and counseling. Such as not having ATP, student psychology test results data, sociometry, and absence of guidance board.

Budgeting for guidance and counseling according to Mr. Eh, vice-principle of madrasah of student affairs and Mrs. Sh, vice-principle of madrasah curriculum affairs said that "The budget is planned and used by counselors for guidance and counseling in character building students using committee funds. But this is contrary to the statement from the coordinator of guidance and counseling. The results of the interview with the coordinator of it on budgetary cuts for guidance and counseling as follows: "Speaking of budget issues, as a teacher I have never made a budget pack, because there is also nothing. But, maybe in the next episode. We are always positive. Hopefully in the future there will be a budget. Like a home visit it will cost you, but we, shame on the pack asked for transportation, although I together with Mr. Nv knows to make a plan that requires a budget, but that's 
again that was it." (interview, 2021). Then when conducted interviews with teachers guidance and counseling, he also said that never proposed and planned a budget for guidance and counseling in the character building of students, so far both counselors use their personal funds.

Based on the above statement, it can be known that the planning guidance and counseling in MTs PPKP Sampit is not in accordance with the planning rules that should be. Among other things, it has not done analysis of students' needs, and analysis of school situation and condition. Analysis of students' needs is very important, because with this analysis, it will be known the needs of services and guidance that will be outlined in the guidance and counseling program. Although the collection of documents has been done by the guidance and counseling teachers in the form of data documents about the child's and the parent's background obtained from the administration, teachers, as well as from students and parents directly. This is not in accordance with the formulated by the Ministry of National Education, which states that the preparation of guidance and counseling programs begins with assessment activities, namely environmental assessment and assessment of students' needs. (Ministry of National Education, 2008: 220)

The process of preparing guidance and counseling programs is carried out by teachers of guidance and counseling at the beginning of the school year without any analysis of the needs of funds to analyze the situation and condition of madrasahs, and never submitted to the head of the madrasah for approval. But the socialization process is still carried out to teachers and education personnel in MTs PPKP Sampit, despite its non-formal nature. Planning facilities and infrastructure to support the implementation of guidance and counseling program services have not met the requirements of the specified standards. This is not in accordance with the principle of guidance and counseling, namely the principle of confidentiality that requires the confidentiality of all data and information about the counseling that is targeted by the ministry, namely data or information that should not or should not be known by others. In addition, according to the Ministry of Education, the provisions of the guidance and counseling room consist of a living room, administration room, individual counseling room, group guidance and counseling room, therapy biblio room, relaxation room, and living room. Budget planning should also be considered because the budget is needed to implement the service program. However, the specific budget for the guidance and counseling program has never been planned by the two counselors, in which case the two counselors use their personal funds in carrying out the service program.

\subsection{Implementation of Guidance and Counseling in the Development of Student Character in MTs PPKP Sampit.}

Implementation of identification of needs and problems. In the implementation of guidance and counseling, the first thing a guidance and counseling teacher should do is to identify the needs and problems of learners, by spreading DCM (Problem Checklist) to all students. But it has not done by both GC teachers. Usually in the implementation of guidance and counseling, the first thing that is done is to ask all teachers to cooperate, and then obtain new student data from the administration. then the data is cross-checked with students, from there it will be known what problems experienced by students. (interview, 2021)

The principals of the madrasah was also involved in identifying the needs and problems of the students. For example, in the morning, students arrive at the front gate of the madrasah to be greeted, and greeted by the head of the madrasah and the teacher who pickets. That way teachers and madrasah principalmust know better the condition of students from the beginning of student present if there are students who are often incomplete in using school attributes or arrive late, surely will be sought for the cause of the problem. From these findings, can be taken some points that can later be used as a Need Assessment in the provision of guidance and counseling services.

The implementation of guidance and counseling in MTs PPKP Sampit is tailored to the vision and mission of madrasah and carried out by two teachers of guidance and counseling. In its implementation, guidance and counseling refers to semester programs and annual programs that have been created. An annual program is a one-year time allocation plan to achieve a set goal. The annual program is a program that includes semester programs and monthly programs that will be implemented by MTs PPKP Sampit for one year of lessons in the first semester. Semester Program. 
The semester program is the description of the annual program. The semester program contains the identification of the needs and problems of students, and the subject matter to be delivered in one semester in the implementation of guidance and counseling in MTs PPKP Sampit.

Based on the results of interviews the implementation of guidance and counseling services carried out in MTs PPKP Sampit there are four areas, namely personal, social, learning, and career fields. "As learned, guidance and counseling in the education unit covers four areas of service, namely the field of services that facilitate personal, social, learning, and career development (interview, 2021).

Implementation of Four guidance and counseling services. Guidance is the process of assisting individuals to achieve self-control and self-direction that is needed to adaptation to schools, families, and the Miller community (in Jones, 1987). According to Tohirin (2007), Syamsu Yusuf L.N. (2005), Prayitno\&ErmanAmti. (2004), DewaKetutSukardi and Insistence P.E. NilaKusmawati (2008) the functions of guidance and counseling at schools as follows; a) Understanding function, b) Preventive function, c) Development Function, d) Healing function. e) Distribution function, f) Adaptation function, g) Adjustment function. h) Repair function, i) Facilitation function, j) Maintenance function, which is a function of guidance and counseling to be able to maintain themselves and a conducive situation that has been created in it.

The four services mentioned throught the guidance and counselingteachers above, each field of service has different objectives for each grade level. Personal guidance, the objectives are as follows: students / konseli have the awareness to worship sincerely, be honest, grateful, love your beloved Indonesian culture, be responsible, manage anger, not inferiority, get enough parental attention, good physical and spiritual health, be able to explore your own potential, know the advantages and weaknesses it has, improve the standard of living / family economy, manage the schedule of daily activities well, know yourself, realize and understand the changes that occur in adolescence, discipline yourself in life and have an independent personality. Social guidance, the objectives are as follows: avoiding the dangers or impacts of cigarettes, doing three important words in association, interacting with teachers and school staff, adapting to the new school environment, being easy to get along with friends at school, overcoming problems with friends at school, easily finding and enjoying friends, understanding about bullying and how to treat it, controlling the use of social media as needed, interacting with the opposite gender according to applicable norms, awareness as a social being that must interact. Learning guidance, the objectives are as follows: students / konseli have the awareness of parents that care about their children's learning activities, gain ease of understanding lessons, do learning disciplines, do learning habits, learn at home, do not delay school task, can earn or achieve achievements in school, have learning motivation, do good group learning. Career guidance, the objectives are as follows: Students / konseli have an understanding of how to learn in good, find a suitable way of learning, obtain scholarship information, the ability to manage work and school time, choose the appropriate Extracurricular, have an optimistic attitude, go up the class, identify ideals that suit him, understand about the types of professions in society, know the OSIS (Intra School Student Organization) and activities that could be understood the relationship of hobbies, talents, interests and abilities.

Then the results of the next interview are also known that, in addition to the services mentioned above, the guidance and counseling teachers also provide a number of services to students in MTs PPKP Sampit, namely orientation services, information services, placement and distribution services, individual counseling services, and group counseling services. Here is the excerpt of the interview with Mrs. WW: "...... In addition to the services mentioned yesterday, other services that we provide are orientation, information, distribution and placement services, individual and group counseling.

Implementation of Individual and Group guidance and counseling. The techniques used by guidance and counseling teachers in the implementation of guidance and counseling in MTs PPKP Sampit include: Classically, that means the technique of implementing guidance and counseling carried out in the classroom using the method of lectures and question and answer, without using multimedia owned by madrasahs or other media around madrasahs.

Individually, that means guidance and counseling services one by one, (one teacher facing one student), in this service usually students who come in are called by counsellors for violating the madrasah rules of conduct. So it is not on the consciousness or will of the learners themselves. This is 
in accordance with the results of the following interviews: the implementation of guidance and counseling activities has not been in accordance with the planned program, there is no regular scheduled coaching of students, especially those who have indications of violations, there is new coaching, handling in the form of sanctions when violations occur. as a real example of violations of student dissipance, such as delays in attending school, the way students dress that are not in accordance with the rules, this keeps repeating. So, the implementation of guidance and counseling in MTs PPKP Sampit should be further enhanced by increasing the number of GC teachers. It is necessary to improve again because there are still troubled children who have not received counseling guidance services on an ongoing basis, this may be due to the number of GC teachers who are still lacking.

In groups, students are gathered in groups that will receive group services such as group guidance or group counseling. This is done if the violation of the madrasah code of conduct is more than one person at the same time, such as delays in coming to madrasahs, skipping, or other mistakes.

Then the mechanism in handling problematic students is carried out in stages. Mr. Eh, stated as follows: "It is carried out in stages, from picket teachers, homeroom teachers, guidance and counseling teachers and then deputy heads of student madrasahs in coordination with the head of madrasahs, depending on the coaching or type of student violations. (interview, 2021). Then Mr. NJ, as a counselor stated: "We always coordinate with the picket teacher or with the homeroom teacher in case of minor violations. But if the violation is serious, then we will coordinate with the vice-principal of student affairs, and also with the vice-principal of curriculum affairs." Slightly different from the statements from Vice-principal of student affairs and counselors, vice-principle of curriculum affairs state as follows: "Although the expected output has not been $100 \%$ achieved, but so far the policy on the implementation of guidance and counseling services has been very good in shaping the discipline and social care of children. When there are violations, for example students arrive late, then the handling is carried out in stages, starting from the teacher picket, coordinating with the maple teacher or homeroom teacher, new to the guidance and counseling teacher. Although sometimes there are also mis, guidance and counseling teachers directly handle without coordination with the homeroom teacher."

From the expose of data above, it is known that the implementation of guidance and counseling programs has been running with the entry hours of classes to perform classic services on a regular basis one hour of lessons per class per week. In addition, there are services that are carried out incidentally. The types of services performed are:

a. Basic services, consisting of class guidance, onboarding services, information services, placement and distribution services.

b. Responsive services, consisting of individual counseling services, group counseling services and collaboration with subject teachers or homeroom teachers.

c. Supporting activities, consisting of data sets, hand-handed cases and home visits.

The type of service welded is not in accordance with the standard of service that should be. According to the Ministry of National Education, the types of services that should be implemented consist of:

a. Basic services, consisting of classroom guidance, orientation services, information services, group guidance, and data collection services.

b. Responsive services, consisting of individual counseling, group counseling, referrals, collaboration with subject teachers or homeroom teachers, collaboration with parents, collaboration with parties outside the school, consultation, peer guidance, case conferences, home visits.

c. Individual planning.

d. System support consists of professional development, program management and development. (ministry of national education, 2008: 228)

Some services have been well implemented, such as class guidance services, onboarding services, and information services. In addition to collaboration with subject teachers or homeroom teachers, home 
visits services have also been well implemented. Services that have not been optimally performed such as group services, individual and group counseling services, this occurs because the ratio amongGC teachers is not ideal, also because of the lack of available facilities, namely guidance and counseling rooms that are not presentative. Individual services are not performed, this is related to unplanned support activities by counsellors such as environmental and student assessment of needs or problems.

Thus the guidance and counseling model in an Islamic middle school, in giving birth to the quality of services who have good character, the researcher can theoretically describe as follows;

\section{Guidance and Counseling}

Teachers of Guidance and Counseling

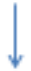

Environmental and Need Assessment

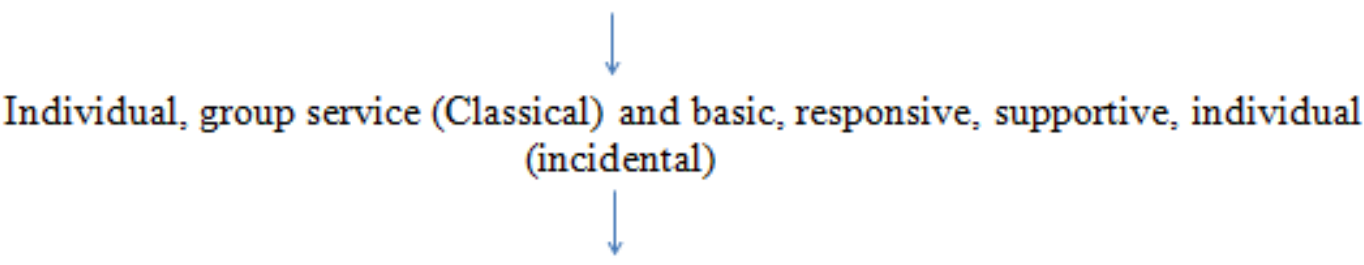

Good character of Student of Islamic Middle

Implementation of preventive guidance and counseling in character building. Implementation of guidance and counseling in MTs PPKP Sampit in an effort to prevent or prevent violations of madrasah regulations by students, based on interviews is not maximum, "because there is no coaching or scheduled service, only incidental service, so there is no prevention efforts against violations, especially severe violations of students. Similarly, when this was asked to the deputy head of madrasah, If judging from the amount of time provided for guidance and counseling services I think it is still not maximal. Because per week students are only available face-to-face time for $1 \times 40$ minutes only. Then I think that so far there have been almost no preventive efforts made by GC teachers in the efforts to enforce student discipline as well as efforts to further foster student social care". Guidance and counseling teacher efforts must be more maximal to foster student discipline and a sense of social care. "Our efforts as a school about the character of students, especially in the character of discipline and social care, are to consistently instill a culture of discipline and social care in the madrasah environment. Not only does it act when there are violations, but there must be efforts to prevent a recurrence of mistakes made by students, especially discipline issues that are very visible. Then I feel a bit concerned, because in my judgment, our students were too ignorant of others, when there are friends who are affected by disasters, only a small number who want to contribute, it must also be visited by students or picket teachers, otherwise more and more will not want to contribute, this signifies that the attitude of social care owned by our students is still very lacking". (interview, 2021)

Related to character building, planning guidance and counseling in PPKP MTs sampit stated by counsellors: First the information we get from the administration, then the second is information from teachers, then we provide understanding, give examples of what will be done in the future, because without the understanding and knowledge of children will not know how discipline behavior should be done by children. For social care, I think our children have been very extraordinary, sir, so I don't think that's a top priority in guidance and counseling program planning.

Furthermore, a statement from the coordinator of guidance and counseling at MTs PPKP Sampit, Mrs. WWas follows: "Honestly sir that is my problem as a GC teacher who every day that I am claustrophobic in me tu, the problem of dissipation and social care of the child, we see that they come out of a background whose parents' education is low, the background and work of non-formal parents , we do not deny that the level of education of parents is very influential with the child, very influential, very influential on the character of the child. Therefore, in every planning I always put 
forward the character of discipline and this sense of social care sir. Then according to Mrs. TE as one of the homeroom teachers involved in guidance and counseling, she stated that "the most urgent thing to note and need to be done coaching by the teacher guidance and counseling in guidance and counseling is the issue of discipline and morality of students. In line with the statement above, Mrs. US also revealed that the most urgent thing to note and need to be done coaching by GC teachers in guidance and counseling is the problems faced by madrasah, students such as learning difficulties and discipline attitudes of students".

According to SW, a grade VIII E student who had been given guidance by a GC teacher, she stated that she felt satisfied enough with the services provided, although she often made the same mistake but she was only given a light punishment and asked to make a statement not to repeat again. They have been quite good and satisfactory in providing guidance and advice, although fear every time called, but they never give burdensome punishments, and we are also always recorded in the case book and make a statement not to repeat again, that's all sir. (interview, 2021)

\section{CONCLUSION}

The implementation of guidance and counseling program has been running with the number of class hours to perform classic services on a regular basis one hour of lessons a week. Then there are some services that are carried out incidentally. But the implementation of the services that should be provided is not all carried out such as group counseling services, as well as supporting activities such as instrument applications and data sets do not exist.

Due to the lack of ability of counsellors in creating service programs, as well as the lack of infrastructure owned by madrasahs, the implementation of guidance and counseling services did not run optimally, as a result of violations of madrasah discipline, especially in terms of discipline continues to repeat itself. The guidance given is incidental so that it gives less deterrent effect.

\section{REFERENCES}

[1] Arikunto, Suharsimi, ProsedurPenelitianSuatuPendekatanPraktek.Rev.ed, Jakarta:PT. RinekaCipta, 2002.

[2] Bungin, BurhanAnalisis Data PenelitianKualitatif, Jakarta: PT. Raja GrafindoPersada, 2003.

[3] Depdiknas, PenataanPendidikanprofesionalKonselordanLayananBimbingandanKonselingDalamJalurPendidikan Formal.Jakarta: BP. Cipta Jaya, 2008.

[4] DidinKurniadindan Imam Machali, ManajemenPendidikan:KonsepdanPrinsipPengelolaanPendidikan, Jogjakarta: Ar-Ruzz Media, 2012.

[5] Duroyaiye, M.O. (1999). Cross-cultural perspectives on guidance and counselling Lagos: Nelson Federal Ministry of Education (2004) National policy on Education, Lagos.

[6] Fathurrahman, Pupuh, PengembanganPendidikanKarakter, Bandung : PT. RefikaAditama.

[7] H.D Sudjana, Manajemen Program PendidikanUntukPendidikanNonformaldanPengembanganSumberDayaManusia, Bandung: Falah Production, 2004.

[8] Hallen, BimbingandanKonseling, Jakarta: CiputatPers, 2012.

[9] Hibana, BimbingandanKonselingPola 17, Yogyakarta: UCY Press, 2013.

[10] Hikmawati, Fenti, BimbingandanKonseling, Jakarta : Raja GrafindoPersada, 2011.

[11] Indrawan, RullydanR.PoppyYaniawaty, MetodologiPenelitian, Bandung :PTRefikaAditama, 2016.

[12] Khasanah, Holifatul, ManajemenBimbingandanKonseling yang di Terapkan di SMA Ma'arifBeranNgawi, Ngawi, 2015.

[13] Kurniasih, Imasdan Berlin Sani. PendidikanKarakterInternalisasidanMetodePembelajaran Di Sekolah.Kata Pena.Yogyakarta : 2017.

[14] Latipun, PsikologiKonseling, Malang: UMM Press, 2010.

[15] Manulang, Dasar-DasarManajemen, Yogyakarta: GadjahMada University Press, 2002.

[16] Matondang, AnasMonandar, Prayitno\&Yahya Jaya, Pelaksanaan TugasPokok Pengawasdalam PelayananBimbingandanKonselingSekolahMenengah Tingkat Atas, Jurnal, Konselor, Volume: 5 No.4, Desember 2016.

[17] Milles, dkk.,Analisis Data Kualitatif, Jakarta: Universitas Indonesia (UI-Press), 2002.

[18] Moleong, Lexy J., MetodePenelitianKualitatif. Bandung: PT. RemajaRosdakarya, 2004. 
Guidance and Counseling Implementation Model in Strengthening of Student Character of Islamic Middle School

[19] Mujib, Abdul dan Dian Andayan, PendidikanKarakterPerspektif Islam, Bandung: PT RemajaRosdakarya, 2012.

[20] Nurihsan, AchmadJuntika\&AkurSudianto, ManajemenBimbingandanKonseling di SekolahDasar, Jakarta: PT. Grasindo, 2005.

[21] Samani, MuchlasdanHariyanto, Konsepdan Model PendidikanKarakter, Bandung: PT RemajaRosdaKarya, 2011.

[22] Sehono, ManajemenBimbingan Dan KonselingDalamPembinaanSiswa di SMK Muhammadiyah 2 JatinomKabupatenKlaten, Tesis Magister, Klaten, 2019.

[23] Siswanto, PengantarManajemen, Jakarta: BumiAksara, 2006

[24] Sudianto, AkurdanAchmadJuntikaNurihsan, ManajemenBimbingandanKonseling di SMP, Jakarta: Grasindo, 2010.

[25] Sudjana, Djudju, Evaluasi Program PendidikanLuarSekolah, Bandung: PT RemajaRosdakarya, 2006

[26] Sugiyo, ManajemenBimbingandanKonseling, Semarang: WidyaKarya, 2012.

[27] Sugiyono, MetodePenelitianKuantitatif, Kualitatif, dan R \&D, Bandung : Alfabeta, 2012.

[28] Sukardi, DewaKetut, BimbinganKarir di Sekolah-sekolah, Jakarta: Ghalia Indonesia, 1989.

[29] Sukardi, DewaKetut, PengantarPelaksanaan Program BimbingandanKonseling di Sekolah, Jakarta: RinekaCipta, 2008.

[30] Suleman, IdentifikasiKarakterPesertaDidikMilenial Dan EfeknyaTerhadapMotivasiBelajar Serta Peran Guru Bimbingan Dan Konseling Di SMP Negeri 1 PerbaunganKabupatenSerdangBedagai, Tesis Magister, Medan, 2019.

[31] Sultani, DalmiIskandar, "ManajemenBimbinganKonseling di SMP Negeri 1 BatangKuis Deli Serdang”,JurnalPenelitianPendidikanSosialHumaniora, Vol. 2. No. 2, 2017.

[32] Supriyanti, Helmi, ManajemenBimbingan Dan Konseling di SekolahMenengahAtas 1 Sampit,Tesis Magister,IAIN Palangkaraya, 2017.

[33] Tohirin, BimbingandanKonseling di Sekolahdan Madrasah (berbasisintegrasi), Jakarta: Raja GrafindoPersada, 2007.

[34] Tohirin, MetodePenelitianKualitatifDalamPendidikan Dan BimbinganKonseling, Jakarta: PT. RajagrafindoPersada, 2011.

[35] Wahjosumijdjo, KepemimpinanKepalaSekolahTinjuauanTeoritikdanPermasalahannya, Jakarta: PT Raja GrafindoPersada, 2003.

[36] Wibowo, Agus, PendidkanKarakter : StrategiMembangunKarakterBangsaberperadaban, Yogyakarta : PustakaPelajar, 2012.

[37] Wiyani,NovanArdi,ManajemenPendidikanKarakter; KonsepdanImplementasinyadisekolah, Yogyakarta: PT PustakaInsanMadani, 2012.

[38] Yaumi, Muhammad, PendidikanKarakterLandasan, Pilar, danImplementasi, Jakarta: Prenada Media Groub, 2016.

[39] Yusri, ManajemenBimbingandanKonselingdalamPembinaanSiswapada SMA di Kota Sabang, Tesis Magister, Sabang, 2016.

[40] Zubaedi, DesainPendidikanKarakterKonsepsidanAplikasinyadalamLembagaPendidikan, Jakarta: Kencana, 2011.

\section{AUTHORS' BIOGRAPHY}

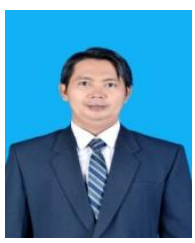

Riyono, is a student of Postgraduate Studies of State Institute for Islamic Studies (IAIN) Palangka Raya, in addition he is a principal of MTs PPKP Sampit Central Kalimantan, he Pursues his research interest in Management of Education, Guidance and Counseling in School.

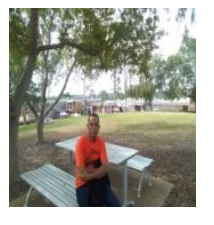

M. Ali Sibram Malisi, is a Doctor in Islamic Education, lecturer in Postgraduate Studies of State Institute for Islamic Studies (IAIN) Palangka Raya, Central Kalimantan. Some international experiences: shortcourse Research Methodology in Leiden University, Netherland, 2016; as a speaker and Republic of Indonesia Government's Delegation together with scholars from gulf countries, Europe, Asia, Africa in international conference "Risalah Amman" in Amman, Jordan, 2017; as guest lecturer and speaker of able people conference in Ma'din academy, Kerala, India, 2017; Postdoctoral Fellowship 
Guidance and Counseling Implementation Model in Strengthening of Student Character of Islamic Middle School

in Western Sydney, Australia, 2018. His research interest include in Management of education, Science of Education, Islamic Education, Gender and Islam, Sociology of Education, and also study of Islamic Boarding School (Pesantren and madrasah).

Citation: Riyono, M. Ali Sibram Malisi. " Guidance and Counseling Implementation Model in Strengthening of Student Character of Islamic Middle School" International Journal of Humanities Social Sciences and Education (IJHSSE), vol 8, no. 3, 2021, pp. 11-25. doi: https://doi.org/10.20431/2349-0381.0803002.

Copyright: (C) 2021 Authors. This is an open-access article distributed under the terms of the Creative Commons Attribution License, which permits unrestricted use, distribution, and reproduction in any medium, provided the original author and source are credited. 